he spent a winter in a snow cave on half rations. On his return from the south in 1913, Priestley entered Christ's College, Cambridge, as a fellow commoner and research student with the view of working up the results of the expedition. On the outbreak of the War, Priestley was commissioned in the London Wireless Signal Section and served in France. At the end of the War he spent some fifteen months writing the official history of the signal service in the War. On returning to Cambridge he studied for the agricultural diploma and was appointed lecturer in soil science. In 1923 he was elected a fellow of Clare College.

Since then, Mr. Priestley has devoted himself almost entirely to administrative work. In 1923 he was appointed secretary of the Board of Research Studies, in 1926 secretary of the Board of Examinations, and in the same year secretary of the newly constituted General Board of Studies. In all these offices Mr. Priestley has been a conspicuous success. The introduction of the new University statutes altered the whole character of the General Board of Studies. The magnitude and importance of the work of the Board has steadily grown during the past eight years, and in the spring of this year a new statute was approved creating a new office of Secretary General of the Faculties, an office which was placed in Schedule B. Mr. Priestley was appointed first Secretary General of the Faculties and appointed to a professorial fellowship at Clare College. As secretary of the Board of Research Studies he has been of very great help to the large number of research students at Cambridge, more particularly to those from abroad. Many of them will welcome him on his arrival in Australia. His departure from Cambridge will be a great loss both to his College and to the University, but he will carry with him the best wishes of his many friends at Cambridge, who are confident that the University of Melbourne will gain very greatly by his appointment.

\section{Food Research}

Is a paper on "the Research Movement and its Modern Developments", read at the spring meeting of the Manufacturing Confectioners' Alliance and the Food Manufacturers' Federation at Harrogate on May 13, Mr. A. L. Hetherington reviewed the way in which scientific research was being applied alike to industrial processes and to everyday life. Particular reference was made to the work being carried out under the Department of Scientific and Industrial Research through the various Research Associations, and more especially to the work of the Cocoa, Chocolate, Sugar Confectionery and Jam Manufacturers and of the Food Manufacturers' Research Association. The successful solution of the problem of bloom on chocolate was the result of a concentrated attack by a team of workers at the problem. Methods have been found of preventing mould growth and fermentation in jams, jellies, fondants, etc., without using prohibited preservatives, and the discovery of a method of slowing down the breakdown of the sugar in re- heating sugar syrups has led to considerable savings in the use of high-grade sugars. Effective work has been done to combat infestation by the cocoa moth and other pests, and the Research Association's work has not only tended to raise the quality of the goods produced but also stimulated interest in the application of science and in the underlying principles of manufacture. In the view of the Advisory Council, no Research Association should be operating on a smaller scale than a minimum income of $£ 10,000$ $£ 20,000$ per annum, and Mr. Hetherington urged fuller support for the two food associations to raise their income to this minimum from the present inadequate $£ 7,000$ and $£ 2,000$ per annum.

\section{Electric Shut-Down in London}

THE sudden cessation of the supply of electricity over London and part of the south-east of England during midday on July 29 proves that even with the best machinery a breakdown in the supply is a possibility that has to be guarded against. Luckily it is an extremely rare occurrence. The trouble started apparently when the engineers were rearranging sections of the supply at the Battersea power station. A small section becoming overloaded, the automatic circuit breaker came into action. When the circuit breaker was closed the currents in two of the sections were probably not in synchronism and so a huge current circulated in the link connecting Battersea with the neighbouring station at Deptford West. The former had an output of 70,000 kilowatts at this moment and the latter of 90,000 . The devices at Battersea declined to take the short circuit load, and several of the machines at Deptford shut down. The Barking Power Station had now to take the load, but the circuit breaker at Northfleet opened and the whole system ceased to operate. The effect was that the whole of the south-east area of the grid was suddenly deprived of 280,000 kilowatts of generating plant. The stations at Norwich and Brighton cleared themselves from the grid, the latter for about an hour. This affected the Southern Railway. The trouble was probably caused by the engineers taking advantage of the light load in summer to cut out certain transmission connexions for overhauling and so the grid system was not in full commission. It was not able to face the loss of Battersea, Barking and Deptford and still keep the whole system working. Notes on this shut-down are given in the Electrical Times of August 2.

\section{Early British Camp}

An important discovery of, it is conjectured, either an early British camp or the site of the eapital of one of the Kentish kings, is announced in the Times of August 6. The site is at Bigberry Woods, near Canterbury, and its exploration, which will occupy two seasons, has been undertaken by a committee, of which Lord Conway of Allington is chairman and Messrs. R. F. Jessup and N. C. Cook of the Maidstone Museum are the joint directors. A number of accidental finds have been made there in the past, 
including a glass jug (Roman) and a large earthenware pot. Other finds have been made-chariot harness and gear, a slave charm and implements. It is thought that the position, occupying about 25 acres on the top of a hill, being a natural strong point, may have been held as a camp up to the time the Romans occupied the valley where Canterbury now stands. Cuttings have been made on the north side and have brought to light a ditch fillud with rubble, broken earthenware and vegetable matter. The excavators have also found a rampart and a black occupational level which contains much broken pottery. More pottery was found in a cess-pit, but a cooking pit, flint-lined, serving a group of wattle and daub huts, contained little pottery. Excavations have also been begun on the south side, whence most of the previous material has come.

\section{Control of the Bed-bug}

THE Ministry of Health has recently issued two brochures dealing with the bed-bug, its habits and methods of eradication. While this insect is not known to be actually concerned with the transmission of the pathogenic organisms of any specific disease, its presence in large numbers is a menace to humanity. The insect is perhaps responsible for ill-health from lack of sleep due to skin irritation, and its presence accentuates the already insanitary conditions under which it thrives. During recent years, the problem of its eradication has come more and more into prominence in connexion with slum clearance and other schemes. A large number of tenants 'of 'council houses' come from verminous dwellings, and the need for ensuring that the new houses are not similarly infested from the outset is a matter of concern to the local authorities. A report of the Committee on the Eradication of Bed-bugs has recently been issued (Reports on Public Health and Medical Subjects. No. 72. 1934.46 pp. H.M. Stationery Office, $1 s .0 d$. net). This Committee, under the chairmanship of Dr. G. W. Monier-Williams, has, in its report, summarised the present position and indicated the lines along which future work on bed-bug control might be profitably undertaken. The life-history of the insect is discussed, and various methods of control are dealt with. In view of the lack of accurate information as to the bionomics and habits of the insect, various lines are emphasised along which research requires to be carried out. The report is accompanied by two well-executed coloured plates, illustrating various phases in the life of the insect, together with an excellent annotated bibliography.

ThE second brochure issued by the Ministry of Health on this subject (Memo. 180 Med.) is entitled "Memorandum on the Bed-bug and how to deal with it". It is intended for official use and has been prepared with the view of assisting sanitary officers and others in dealing with bed-bugs. It outlines the biology of the insect, gives instructions where to seek the insects, and cites the chief means of prevention and the best methods of extermination. For fuller information on the subject the report, already mentioned, should be referred to. The memorandum is accompanied by the same coloured plates as are appended to the report. We welcome the appearance of these two publications since they supply, in non-technical language, accurate and upto-date information on a long-standing problem. Its full solution is dependent upon research carried out along the lines indicated, and much remains to be done. Relatively little is known, for example, of the effects of climatic conditions on the breeding of the insect, or as to the extent to which it can survive on the blood of other animals in the absence of human beings. There is, also, much yet to be discovered with regard to the differential action of insecticides on the insect and its eggs. The effects of heavy infestation of bed-bugs on the general health of the people are still not properly understood, and there is real need for definitely ascertaining whether, under certain conditions, bed-bugs may prove to be the carriers of disease germs.

\section{A New Skymeter}

IN these days when many of our great cities are involved in so much rebuilding, the question of light easements of adjoining property frequently gives rise to the necessity for financial settlements or building restrictions involving a definite assessment of rights of light existing. Speaking generally, the law recognises that light enjoyed over a sufficient period, so far as the use to which the particular space lighted is usually put, cannot be materially encroached upon without some form of compensation. At one time, cases in the courts depended on such general evidence as could be brought forward ; more recently, geometrical methods have been worked out whereby the actual illumination can be measured. These methods are laborious, and Mr. A. S. E. Ackermann, 17 Victoria Street, London, S.W.I, sends us particulars of an invention for determining sill ratios which involves neither photographic nor photometric work. It consists of a pane of clear glass attached to two adjustable radius bars, the whole mounted on a stand. This is set up to face the window in question with the centre of the glass at the middle of the sky area. The sine of the elevation is read and the sky area traced on the glass, the observer using a pinhole eyepiece. This diagram is transferred to tracing paper and the sky area measured by a planimeter. This area multiplied by the sine of the elevation angle and divided by a constant gives the sill ratio. The instrument is portable and weighs less than $9 \mathrm{lb}$.

\section{Skating Rinks and Wave Bathing Pools}

ICE skating rinks and wave bathing pools, being used mainly for pleasure, have until quite recently not been seriously studied from the engineering and scientific point of view. The Dolder ice skating rink at Zurich which was opened four years ago has proved such a success that Zurich is now the centre of the ice sports in Switzerland. In the Escher-Wyss News of May 1934, D. Mettler describes the open-air skating rink and wave bathing pool in Berne and 